\title{
In vitro gas production of foliage from three browse tree species treated with different dose levels of exogenous fibrolytic enzymes
}

Article in J Anim Physiol a Anim Nutr · April 2016

Impact Factor: $1.41 \cdot$ DOI: $10.1111 /$ jpn.12467

READS

25

8 authors, including:

Hector Aaron Lee Rangel

Universidad Autónoma de San Luis Potosí 15 PUBLICATIONS 41 CITATIONS

SEE PROFILE

\section{Ignacio Arturo Domínguez Vara}

Universidad Autónoma del Estado de Méxic.

66 PUBLICATIONS 210 CITATIONS

SEE PROFILE

\section{Salem, A.Z.M.}

Universidad Autónoma del Estado de Méxic...

262 PUBLICATIONS 945 CITATIONS

SEE PROFILE

\section{Rolando Rojo Rubio}

Universidad Autónoma del Estado de Méxic...

95 PUBLICATIONS 261 CITATIONS

SEE PROFILE 


\title{
In vitro gas production of foliage from three browse tree species treated with different dose levels of exogenous fibrolytic enzymes
}

\author{
D. López ${ }^{1}$, J. F. Vázquez-Armijo ${ }^{1}$, N. López-Villalobos ${ }^{1,2}$, H. A. Lee-Rangel ${ }^{3}$, A. Z. M. Salem ${ }^{4}$, \\ J. L. Borquez-Gastelum ${ }^{4}$, I. A. Domínguez-Vara ${ }^{4}$ and R. Rojo-Rubio ${ }^{1}$ \\ 1 Centro Universitario UAEM Temascaltepec, Universidad Autónoma del Estado de México Temascaltepec, México, Mexico \\ 2 Institute of Veterinary, Animal and Biomedical Sciences, Massey University Palmerston North, New Zealand \\ 3 Facultad de Agronomía, Universidad Autónoma de San Luis Potosí Soledad de Graciano Sánchez, San Luis Potosí, Mexico, and \\ 4 Facultad de Medicina Veterinaria y Zootecnia, Universidad Autónoma del Estado de México El Cerrillo Piedras Blancas, México, Mexico
}

\section{Summary}

The aim of this study was to evaluate the effect of different dose levels of exogenous fibrolytic enzymes (EFE) on in vitro ruminal fermentation kinetics and energy utilization of foliages from three browse trees (Pithecellobium dulce, Heliocarpus velutinus and Guazuma ulmifolia). Mixture of EFE product was added to the leaves of the three browse tree species at three dose levels: 0 (control), 3.5 and $7.0 \mathrm{mg} / \mathrm{g}$ of DM. Chemical composition of the foliages, including plant secondary metabolites such as total phenolics (TP), saponins (SAP) and aqueous fraction $(\mathrm{AF})$, was determined. In addition, in vitro assaying of ruminal gas production kinetics was determined for the three browse three foliages treated with EFE. $P$. dulce had the highest crude protein content $(\mathrm{p}<0.05)$, whereas G. ulmifolia had the highest content of neutral detergent fibre and SAP $(\mathrm{p}<0.05)$ and H. velutinus had the lowest content of TP $(\mathrm{p}<0.05)$. The interaction between tree species and dose level of EFE was significant $(\mathrm{p}<0.05)$ for gas production (GP) at $24 \mathrm{~h}$ of incubation, parameters $b$ and $c$ of the accumulated GP curve, short-chain fatty acids (SCFA) and metabolizable energy (ME). The lowest $(\mathrm{p}<0.01)$ extent of accumulated GP as well as the $b$ and $c$ values occurred in G. ulmifolia at $0 \mathrm{mg}$ EFE/g DM. P. dulce had the highest $(\mathrm{p}<0.05)$ values for ME and SCFA at the highest dose of EFE. Tree species and dose level had significant $(p<0.05)$ effects on all parameters describing in vitro ruminal fermentation kinetics and energy utilization. Addition of EFE improved the fermentation kinetics of the browse species considered in this study.

Keywords browse tree species, exogenous enzyme, gas production

Correspondence R. Rojo-Rubio, Centro Universitario UAEM Temascaltepec, Universidad Autónoma del Estado de México, Km. 67.5 Carretera Federal Toluca-Tejupilco, 51300, Temascaltepec, Estado de México, México. Tel: +52 7162665209; Fax: +52 7162665209; E-mail: dr_rojo70@yahoo.com. $\mathrm{mx}$

\section{Introduction}

Livestock production in tropical and subtropical regions is limited by the scarcity of high-quality feed, mainly during the long dry season (Hove et al., 2001). Some forage as such legume fodder, trees and shrubs present high protein values and are potentially useful to correct the nutrient deficiencies (Camacho et al., 2010a). Tree and shrub leaves are important components of goat and sheep diets and play an important role in small ruminant nutrition under extensive livestock production systems (Salem et al., 2006; Camacho et al., 2010a). However, they also contain some secondary metabolites such as tannins and other secondary compounds (Wina et al., 2005). Tannins are polyphenolic compounds, which occur widely in plants, with the ability to bind proteins and other nutrients. Some tannins can also produce toxic and secondary metabolites in monogastric and ruminant animals and cause reduced intake, lower nutrient digestibility and protein availability (SzumacherStrabel and Cieślak, 2010), although other secondary metabolites, such as saponins, alkaloids, essential oils and the aqueous fraction of lectins, polypeptides and starch, may also have negative impacts on carbohydrates and protein digestion (Salem et al., 2006).

The use of enzymes as feed additive for ruminant diets has attracted considerable interest recently 
(Beauchemin et al., 2003). However, there are increasing evidences indicating that the mode of action of these enzymes in ruminants is a combination of pre- and post-feeding effects (Colombatto et al., 2003). Improvements in ruminant production with supplemental fibrolytic enzymes are generally attributed to increased ruminal fibre digestion, but the exact mechanism is not yet fully understood. Numerous potential mechanisms have been proposed (Beauchemin et al., 2000, 2003; McAllister et al., 2001), including pre-ingestive and ruminal effects such as direct hydrolysis, structural changes in the fibre, increased ruminal microbial attachment, stimulation of ruminal microbial populations and synergism with ruminal microbial enzymes. A product containing cellulases, xylanases, $\alpha$-amylase and proteases from an anaerobic bacterium showed a positive effect on browse leaves degradation in rabbits (El-Adawy et al., 2008), ruminant performance and nutrient utilization of low-quality forages in vivo (Gado, 1997) and in vitro (Gado et al., 2007). Therefore, the objective of this work was to evaluate the effect of different dose levels of exogenous fibrolytic enzymes treatment (i.e. EFE) on in vitro fermentation, gas production kinetics and energy utilization of Pithecellobium dulce, Heliocarpus velutinus and Guazuma ulmifolia leaves.

\section{Materials and method}

Location for sample collection and experimental treatments

Foliages for the three tree species was collected from the South of Mexico state. Geographically, this is located at $19^{\circ} 02^{\prime} 04^{\prime \prime}$ north latitude and $100^{\circ} 02^{\prime} 14^{\prime \prime}$ west longitude at an elevation of 1720 masl. The climate is moderately humid with an average temperature of $15-18{ }^{\circ} \mathrm{C}$ and annual rainfall of 950-1000 mm (García, 1987). Laboratory analyses and in vitro gas production study were undertaken in the Animal Nutrition Laboratory of the Centro Universitario UAEM Temascaltepec, located in the municipality of Temascaltepec de González, México.

\section{Browse species}

During the dry season (April/May), a mixture of young and mature leaves was sampled from three browse species - Pinzan (Pithecellobium dulce), Guácimo (Heliocarpus velutinus) and Cuahuilote (Guazuma ulmifolia) from several locations in the Southern part of Mexico state. Three individual replicates samples $(\sim 2.5 \mathrm{~kg}$ each one pooled of at least 7 trees) were randomly collected. These sam- ples were air-dried in the shade to minimize changes in secondary compounds activity (Makkar and Singh, 1991).

\section{Exogenous fibrolytic enzymes}

The tested exogenous fibrolytic enzyme was a preparation containing xylanase and cellulase activities. According to the manufacturers, this additive (Fibrozyme $^{\circledR}$ ) is a fibrolytic enzyme powder preparation containing xylanase and cellulase activities (Fibrozyme, Alltech, Nicholasville, KY, USA) from Aspergillus niger and Trichoderma viride fermentation which have cellulase and xylanase activity of 31.0 and 43.4 UI respectively. Enzymes activity was determined in the Fibrozyme ${ }^{\circledR}$ according to the methods of Ramírez et al. (2005). Doses of exogenous enzymes tested were as follows: 0 (control), 3.5 and $7.0 \mathrm{mg} / \mathrm{g}$ DM of dried leaves.

\section{Analytical methods}

Fresh samples were dried at $45{ }^{\circ} \mathrm{C}$ for $48 \mathrm{~h}$ for moisture determination and ground in a Willey-mill to pass through a $1-m m$ screen. Samples were assayed in triplicate according to the AOAC (1990) for DM, crude protein $(\mathrm{CP}, \mathrm{N} \times 6.25)$ and ash content by methods 930.15, 976.05 and 942.05 respectively. Neutral detergent fibre (NDF) and acid detergent fibre (ADF) content (Van Soest et al., 1991) were analysed using the ANKOM F-57 filter bags in an Ankom ${ }^{200}$ fibre analyser (Ankom Technolgy, Macedon, NY, USA). For a NDF analysis, samples were treated with $\alpha$-amylase (Sigma A-3403 Sigma-Aldrich ${ }^{\circledR}$, St. Louis MO, USA), and the neutral detergent solution (NDS) contained sodium sulphite and the residues were not corrected for residual ash. Hemicellulose content was calculated from the difference between a NDF and ADF.

Plant secondary metabolites (PSM): total extractable phenolics, saponins and aqueous fraction, were determined by methodology described by Salem et al. (2006). Fresh leaves were chopped $(1-2 \mathrm{~cm})$ and immediately $10 \mathrm{~g}$ of each species were extracted with $80 \mathrm{ml}$ of solvent mixture. The solvents mixture contained $10 \mathrm{ml}$ methanol (99.8/100, analytical grade, Fermont $^{\circledR}$, Monterrey, Mexico), $10 \mathrm{ml}$ ethanol (99/ 100, analytical grade, Fermont ${ }^{\circledR}$, Monterrey, Mexico) and $80 \mathrm{ml}$ distilled water. Plants materials were individually incubated with the solvent in closed flasks at $25-30{ }^{\circ} \mathrm{C}$ for $48 \mathrm{~h}$. After the incubation time, all flasks were incubated in water bath at $39{ }^{\circ} \mathrm{C}$ for $1 \mathrm{~h}$, and then immediately filtered and the filtrates were collected and stored at $4{ }^{\circ} \mathrm{C}$ for further use. 
PSM were determined in triplicate for each plant extract ( $P$. dulce, H. velutinus and G. ulmifolia). $10 \mathrm{ml}$ of extract was fractionated by funnel separation with a double volume of ethyl acetate (99.7/100, analytical grade, Fermont ${ }^{\circledR}$, Monterrey, Mexico) to determine total phenolics (TP) by drying and quantifying the TP layer in the funnel. After TP separation, $20 \mathrm{ml}$ of n-butanol was added (99.9/100, analytical grade, Fermont ${ }^{\circledR}$, Monterrey, Mexico) to fractionate the saponins (Makkar et al., 1998). The remaining solution in the funnel was considered to be the aqueous fraction (AF) that has the other secondary compounds such as lectins, polypeptides and starch (Cowan, 1999).

\section{In vitro ruminal gas production}

\section{Donor animals}

Rumen fluid used for the in vitro gas production of the fodder tree species was withdrawn by stomach tube from four growing goats (Boer, LW $18 \pm 0.3 \mathrm{~kg}$ ) before the morning feed which have the following forage:concentrate (70:30 DM, basis) diet. The forage contained a mixture of oat hay $(677 \mathrm{~g} / \mathrm{kg})$, alfalfa hay $(176 \mathrm{~g} / \mathrm{kg}), H$. velutinus dried leaves $(44 \mathrm{~g} / \mathrm{kg})$ and G. ulmifolia dried leaves ( $103 \mathrm{~g} / \mathrm{kg})$ with a concentrate mixture (210 g CP/kg DM), containing ground sorghum $(380 \mathrm{~g} / \mathrm{kg})$, ground corn $(380 \mathrm{~g} / \mathrm{kg})$, soya bean meal $(120 \mathrm{~g} / \mathrm{kg})$, sugarcane molasses $(80 \mathrm{~g} / \mathrm{kg})$, urea $(2 \mathrm{~g} / \mathrm{kg})$ and minerals $(20 \mathrm{~g} / \mathrm{kg} \mathrm{DM})$. The diet was offered twice daily, and all the animals had access to clean water ad libitum.

\section{In vitro gas production}

The gas production assay was carried out according to the procedure described by Theodorou et al. (1994) as modified by Mauricio et al. (1999). Approximately $\mathrm{l} \pm 0.002 \mathrm{~g}$ of $\mathrm{DM}$ of each species was weighed in triplicate into $160 \mathrm{ml}$ serum bottles. Exactly $250 \mathrm{mg}$ of enzyme product was dissolved in $50 \mathrm{ml}$ of distilled water, and $0,0.7$ and $1.4 \mathrm{ml}$ were added to each bottle. Three hours later, $90 \mathrm{ml}$ anaerobic buffer (containing micro- and macro-elements, a reducing agent and a reduction indicator of resazurin) was added to the bottles (Mauricio et al., 1999), and they were then stored at 20$22{ }^{\circ} \mathrm{C}$ for $17 \mathrm{~h}$ (Colombatto et al., 2007). Thus, total enzyme-feed interaction time was $20 \mathrm{~h}$. Ten millilitres of ruminal fluid, obtained pre-feeding (7:00 h) from the four goats by stomach tube, was inoculated into the bottles. The ruminal fluid was obtained from multiple sites in the rumen, strained through two layers of muslin and then kept at
$39{ }^{\circ} \mathrm{C}$ under a continuous $\mathrm{CO}_{2}$ stream. Negative controls containing buffered rumen fluid with or without enzyme but no substrate, were also included in triplicate for correction of gas produced from small particles present in the ruminal fluid or sugars present in the enzyme products. Cumulative gas production $(\mathrm{ml} / \mathrm{g} \mathrm{DM})$ was recorded at 2, 4, 6 , $8,10,12,15,19,24,30,36,48,72$ and $96 \mathrm{~h}$ postincubation at $39{ }^{\circ} \mathrm{C}$. Volume of gas (ml/g DM) produced after $24 \mathrm{~h}$ of incubation (GP24) was used as an index of energy feed value of tree fodder samples.

\section{In vitro dry matter degradability}

At the end of incubation (96 h), the contents of each serum bottle were filtered using sintered glass crucibles (porosity $1,100-$ to $160-\mu \mathrm{m}$ pore size, Pyrex, Stone, UK) under vacuum. Fermentation residues were dried at $105^{\circ} \mathrm{C}$ overnight to estimate the DM disappearance.

\section{Calculation}

The pressure generated by the gas accumulated in the upper part of the incubation serum bottles was measured through a pressure transducer connected to a digital data reader. The equation was previously obtained using the REG procedure of the SAS (2002) program:

$$
Y=0.024+5.34 X+0.031 X^{2}
$$

where $Y$ is volume $(\mathrm{ml})$ and $X$ is pressure (psi). $R^{2}=0.99$.

Then, gas production data (ml/g DM) were fitted using the NLIN procedure of SAS (2002) with a nonlinear model as described by France et al. (2000):

$$
A_{t}=b \times\left[1-e^{-c(t-L)}\right]
$$

where $A_{t}$ is the volume of gas production at time $t$; $b$, the asymptotic gas production $(\mathrm{ml} / \mathrm{g} \mathrm{DM}) ; c$ is the rate of gas production $(\mathrm{ml} / \mathrm{h})$ and $(\mathrm{L} / \mathrm{h})$ is the lag time.

Metabolizable energy ( $\mathrm{ME}, \mathrm{MJ} / \mathrm{kg} \mathrm{DM})$ was estimated according to Menke and Steingass (1988) as:

$$
\begin{aligned}
\mathrm{ME}= & 2.20+0.1357 \mathrm{GP}_{24}+0.0057 \mathrm{CP} \\
& +0.0002859 \mathrm{EE} 2
\end{aligned}
$$

where $\mathrm{GP}_{24}$ was gas produced after $24 \mathrm{~h}$ of incubation and CP was that crude protein of tree leaves (\% DM). 
Short-chain fatty acids (SCFA) were estimated depending on the relationship $\left(R^{2}=0.94\right)$ between gas production at $24 \mathrm{~h}$ and SCFA concentration of tannin-containing browses following the equation of Getachew et al. (2002):

$$
\text { mmolsCFA }=-0.00425+0.0222(\mathrm{ml} \text { gas at } 24 \mathrm{~h})
$$

\section{Experimental design and statistical analysis}

Nutrient and secondary compounds contents from tree foliage were statistically analysed using the GLM procedure of SAS (2002) with a linear model that included the effect of browse tree species. Least squares means and standard errors for each browse tree species for each dependent variable were obtained and used for multiple comparisons using the Tukey test.

Data for in vitro ruminal fermentation were analysed using a randomized complete design with 3 browse tree species $\times 3$ dose levels of $\operatorname{EFE}(0,3.5$ and $7.0 \mathrm{mg} / \mathrm{g}$ of DM) in factorial arrangement with tree repetitions. The linear model was:

$$
y_{i j k}=\mu+B_{i}+D_{j}+B D_{i j}+e_{i j k}
$$

where $y_{i j k}=$ the dependent variable; $\mu=$ overall mean; $B_{i}=$ effect of $i$-browse tree species; $D_{j}=$ effect of $j$ - dose level of EFE; $B D_{i j}=$ interaction between the $i$-browse tree species and $j$-dose level of EFE; and $e_{i j k}=$ the residual error $\sim$ NI $\left(0, \sigma^{2}\right)$.

Least squares means and standard errors for each browse tree species, dose level of EFE and each combination of browse tree species and dose level were obtained and used for multiple comparisons using the Tukey test.

\section{Results}

Chemical composition and secondary compounds The CP content of $P$. dulce (222 g/ kg DM) was higher $(\mathrm{p}<0.05)$ than the remaining tree species, while G. ulmifolia showed the lowest CP value $(148 \mathrm{~g} / \mathrm{kg}$ DM) (Table 1). G. ulmifolia showed higher $(\mathrm{p}<0.05)$ contents of NDF, ADF and hemicellulose than the other two tree species.

The tree species differed in secondary compounds contents $(\mathrm{p}<0.05)$. P. dulce and G. ulmifolia had higher $(\mathrm{p}<0.05)$ contents of TP than H. velutinus. G. ulmifolia showed the highest $(\mathrm{p}<0.05)$ contents of SAP, while $P$. dulce had the highest $(\mathrm{p}<0.05)$ AF contents.

\section{In vitro rumen fermentation}

Browse tree species and dose level had a significant effect $(p<0.02$ ) on all variables describing the in vitro ruminal fermentation kinetics and energy utilization of foliages, excepting that dose level had no significant effect on IVDMD (Table 2). P. dulce and $H$. velutinus showed higher values of SCFA, ME and IVDMD than G. ulmifolia (Table 2). Addition of EFE improved the in vitro fermentation kinetics of the browse tree leaves (see Table 2 and Figs 1-3). High dose levels of EFE decreased the lag time for all species $(\mathrm{p}<0.05)$.

The interaction between browse tree species and dose level of EFE was significant $(p<0.05)$ for $\mathrm{GP}_{24}$, parameters $b$ and $c$ of the accumulated GP curve, SCFA and ME, but this interaction was not significant

\begin{tabular}{|c|c|c|c|c|c|}
\hline Item & P. dulce & H. velutinus & G. ulmifolia & SEM & p-Value \\
\hline \multicolumn{6}{|c|}{ Chemical composition } \\
\hline $\mathrm{OM}$ & $896.99^{b}$ & $921.92^{\mathrm{a}}$ & $897.59^{b}$ & 0.87 & $<0.0001$ \\
\hline $\mathrm{CP}$ & $222.10^{\mathrm{a}}$ & $154.30^{b}$ & $147.76^{c}$ & 1.23 & $<0.0001$ \\
\hline NDF & $435.23^{c}$ & $455.81^{b}$ & $478.06^{\mathrm{a}}$ & 1.96 & $<0.0001$ \\
\hline ADF & $305.79^{b}$ & $323.57^{b}$ & $368.46^{\mathrm{a}}$ & 6.73 & 0.0002 \\
\hline Hemicellulose & $129.43^{a}$ & $132.23^{a}$ & $109.59^{b}$ & 5.87 & 0.0164 \\
\hline Ash & $103.01^{a}$ & $78.08^{b}$ & $102.41^{a}$ & 0.87 & $<0.0001$ \\
\hline \multicolumn{6}{|c|}{ Secondary compounds } \\
\hline $\mathrm{TP}$ & $51.93^{a}$ & $15.67^{b}$ & $48.93^{a}$ & 2.86 & $<0.0001$ \\
\hline SAP & $16.57^{b}$ & $16.87^{b}$ & $29.40^{a}$ & 0.85 & $<0.0001$ \\
\hline $\mathrm{AF}$ & $157.30^{\mathrm{a}}$ & $133.70^{b}$ & $130.90^{b}$ & 4.49 & $<0.0020$ \\
\hline
\end{tabular}

Table 1 Chemical composition and secondary compounds (g/kg DM) of browse tree species

Means in the same row with different superscripts differ ( $p<0.05)$. OM, organic matter; CP, crude protein; NDF, neutral detergent fibre; ADF, acid detergent fibre; TP, total phenols; SAP, saponins; AF, aqueous fraction; SEM, standard error of the mean. 
Table 2 In vitro gas production at $24 \mathrm{~h}$ of incubation ( $\mathrm{ml} / \mathrm{g} \mathrm{DM}$ ), gas production parameters (b, c and L), energy utilization (ME and SCFA) and in vitro dry matter degradability of three browse tree foliages added with different dose level of exogenous fibrolytic enzymes (mg/g DM)

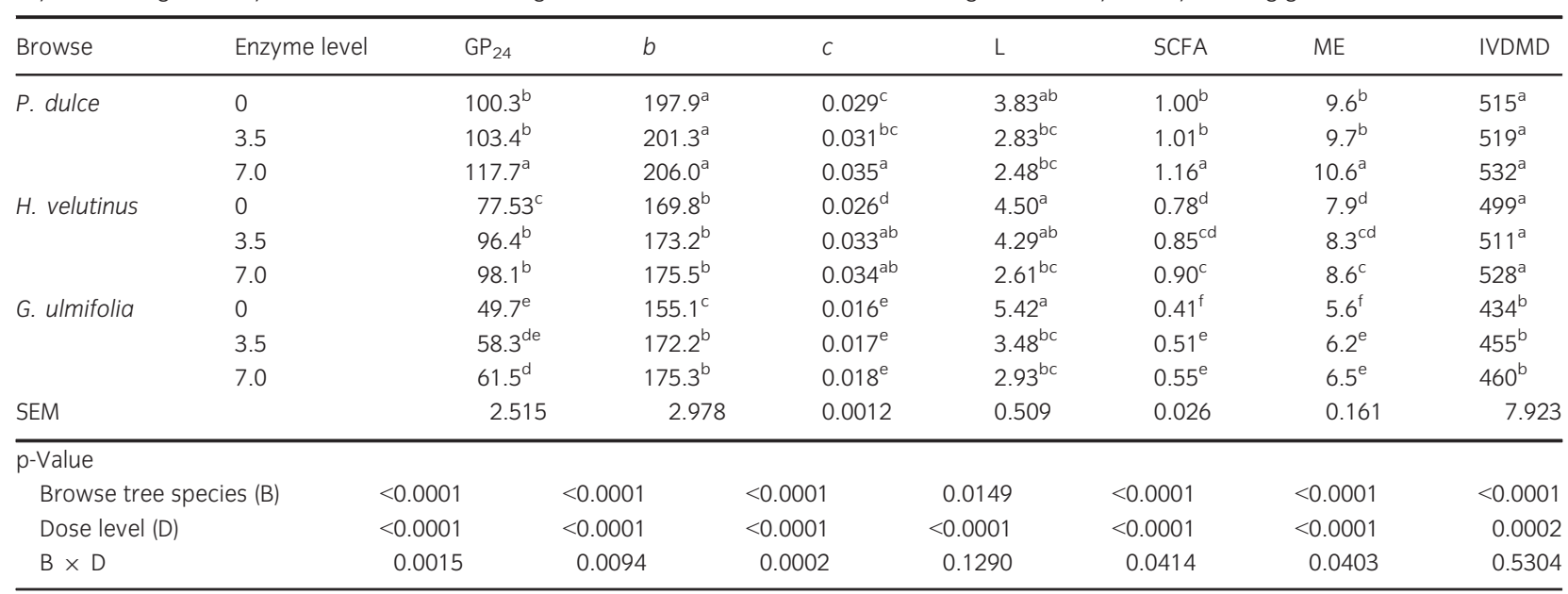

Means within a column with different superscripts differ $(\mathrm{p}<0.05)$. $\mathrm{GP}_{24}$, cumulative gas production at $24 \mathrm{~h}$; $\mathrm{b}$, asymptotic gas production (ml/g DM); c, fractional rate of gas production (/h); L, lag time (h); SCFA, short-chain fatty acid concentration (mmol); ME, metabolizable energy content (MJ/kg $\mathrm{DM})$; IVDMD, in vitro dry matter degradability (g/kg DM); SEM, standard error of the mean.

Fig 1 Cumulative gas production profiles ( $\mathrm{ml} / \mathrm{g}$ DM) from in vitro fermentation of Pithecellobium dulce leaves treated with different dose levels $(0,3.5$ and $7.0 \mathrm{mg} / \mathrm{g}$ of DM) of an exogenous fibrolytic enzyme preparation. SEM is for the overall fit, and $p$ Value is for the effect of enzyme level.

Fig 2 Cumulative gas production profiles $(\mathrm{ml} / \mathrm{g}$ DM) from in vitro fermentation of Heliocarpus velutinus leaves treated with different dose levels $(0,3.5$ and $7.0 \mathrm{mg} / \mathrm{g}$ of DM) of an exogenous fibrolytic enzyme preparation. SEM is for the overall fit and $p$-Value is for the effect of enzyme level.
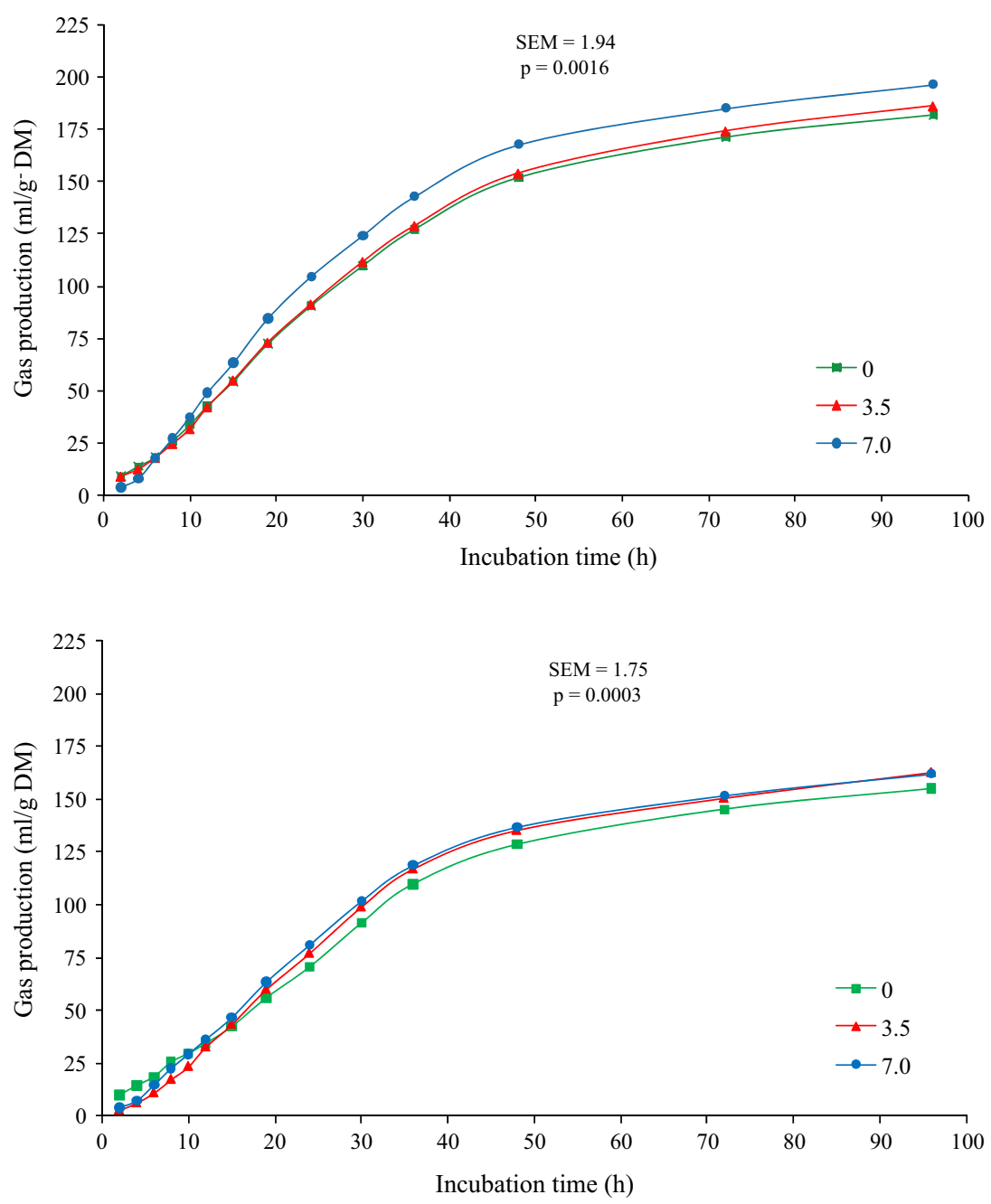


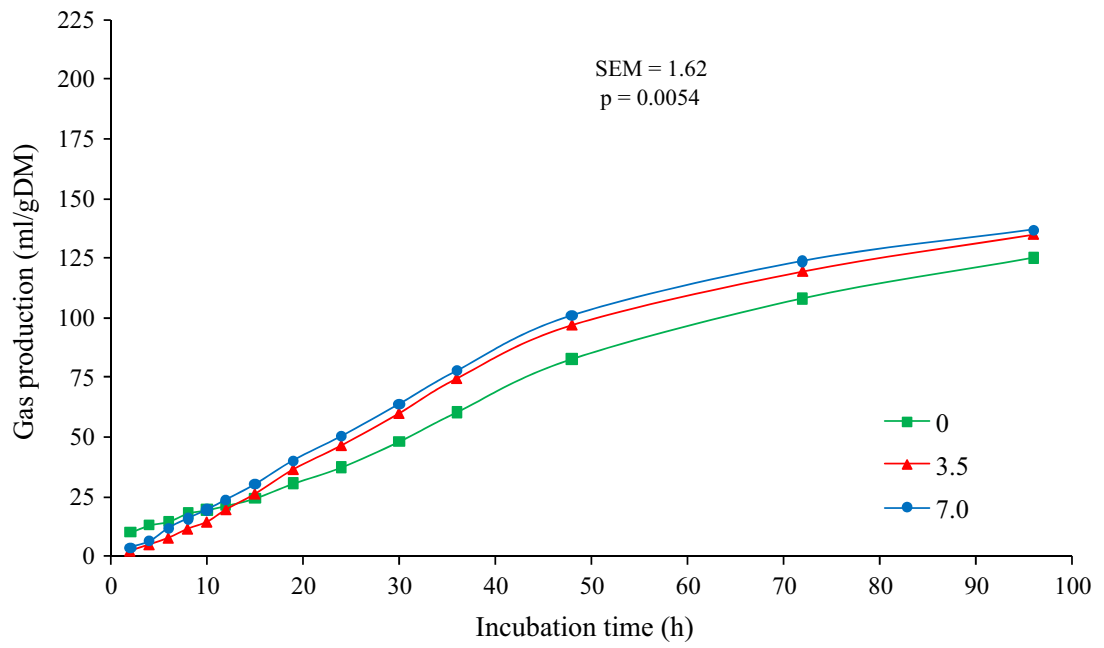

Fig 3 Cumulative gas production profiles $(\mathrm{ml} / \mathrm{g}$ DM) from in vitro fermentation of Guazuma ulmifolia leaves treated with different dose levels $(0,3.5$ and $7.0 \mathrm{mg} / \mathrm{g}$ of DM) of an exogenous fibrolytic enzyme preparation. SEM is for the overall fit, and $p$-Value is for the effect of enzyme level. for L and IVDMD (Table 2). P. dulce treated with the highest dose level of EFE (i.e. $7 \mathrm{mg}$ EFE/g DM) showed the highest $(p<0.01)$ value of $G_{24}$, SCFA and ME. The lowest $(p<0.01)$ extent of accumulated GP as well as the $b$ and $c$ values occurred in G. ulmifolia at $0 \mathrm{mg}$ EFE/g DM.

\section{Discussion}

Browse tree leaves are a useful current option to feed goats during the dry season when availability of higher quality forages is low. Compared with the values reported in this study, Camacho et al. (2010b) reported similar values of $\mathrm{CP}$, NDF and $\mathrm{ADF}$ for $P$. dulce during wet and dry seasons in a region near to the present study site. The CP content of the three browse tree species used in our study indicated that they provide ruminal degradable $\mathrm{N}$ when used as supplements during the dry season in semi-arid regions. Furthermore, the relatively low fibre contents in $P$. dulce and $H$. velutinus suggest that these browse three species will show high DM digestibility ( $\underline{\text { Reed, }}$ 1986; Salem et al., 2006). However, content of secondary compounds such as TP and SAP in $P$. dulce and G. ulmifolia may cause some negative effects, for example, depressing feed intake, impairing digestibility and/or having a toxic effect on rumen microorganisms (Mangan, 1988; Salem et al., 2006). Secondary compounds in foliages are mainly a property of plant genetic factors controlling physiological synthesis and accumulation of secondary compounds (Okuda et al., 1993; Kelman et al., 1997). Other factors associated with high rates of polyphenolic synthesis include high environmental temperatures, drought stress and plant-defensive mechanisms against pests, pathogens and predators (Mangan, 1988).
In vitro GP parameters ( $b$ and $c$ ) appear related to the chemical composition of the substrate, in particular to the fibre content and its structural polysaccharides (Kamalak et al., 2005). The high value of $\mathrm{GP}_{24}$ in $P$. dulce at the highest dose level of EFE suggests a higher extent of fermentation in the first $24 \mathrm{~h}$ of fermentation $v s$. the other leaves, especially G. ulmifolia. Differences in GP among the leaves could be due to the proportion, and nature, of their fibre (Rubanza et al., 2003). Higher asymptotic GP (i.e. $b$ ) of $P$. dulce could be due to its lower fibre and SAP content, although some variation among leaves could be due to genetic characteristics relative to the type of secondary compound activity on digestibility (Salem et al., 2006). Direct-fed EFE have been shown to enhance microbial colonization of feeds by increasing the numbers of ruminal fibrolytic microbes (Morgavi et al., 2004) resulting in an increased degradation rate of ruminal fibre (Giraldo et al., 2008). Pre-treatment of forages with EFE can solubilize some fibre and improve the digestibility at shorts incubation times (Moharrery et al., 2009). However, some research has shown that efficiency of forage utilization was increased at increasing dose levels of EFE (Miller et al., 2008), whereas others suggest that EFE produced better results at a specific level, rather that showing a dose response (Jalilvand et al., 2008). In this study, the interaction between browse tree species and dose level of EFE was significant $(p<0.05)$ for in vitro ruminal kinetics parameters and energy utilization, confirming that efficiency of EFE depends on the forage type and dose level.

The lower GP and energy utilization (ME and SCFA) of G. ulmifolia vs. other browse tree species was probably due to higher fibre contents, as well as high levels of TP and SAP. This effect is probably due to 
reduced microbial adherence of feed particles (McAllister et al., 1994) and inhibition of microbial growth. The antinutritive effects of phenolic compounds in tree and shrub leaves, particularly tannins, are associated with their ability to combine with dietary proteins, polymers such as cellulose, hemicellulose and pectin, and minerals thus retarding the DM digestion (McSweeney et al., 2001). Other secondary metabolites, such saponins, alkaloids, essential oils and the aqueous fraction of lectins, polypeptides and starch, may also have negative impacts on the digestibility of DM (Salem et al., 2006).

However, in our study high dose levels of EFE decreased the lag time for all species. Colombatto et al. (2003) mentioned that enzymes could degrade complex substrates to simpler forms at early stages of fermentation to allow faster ruminal microbial colonization and fermentation. Some authors have suggested that pre-treatment of feed with enzymes could create a stable enzyme-feed complex (Kung et al., 2000), but others have indicated an alteration in fibre structure, which would stimulate microbial colonization (Nsereko et al., 2000).

Increased IVDMD of $P$. dulce and $H$. velutinus reflects its higher fermentation, and lower fibre and saponins content. In contrast, lower values of IVDMD in G. ulmifolia represent less fermentation and higher secondary compound levels (Salem et al., 2006). Digestibility of tree leaves was adversely affected by secondary compounds in vitro (Peng et al., 2005;
Rakhmani et al., 2005) and in vivo (Salem et al., 2006). Rubanza et al. (2003) reported a negative relationship between chemical composition, and phenolic compounds, with in vitro degradability of legumes at $24 \mathrm{~h}$ of in vitro incubation.

\section{Conclusion}

Among the examined browse tree leaves, $P$. dulce had the highest protein content, as well as higher gas production and metabolizable energy, indicating that, of the browse leaves examined, it had the best potential as a ruminant feed. In contrast, the nutritional value of G. ulmifolia was the lowest. This study indicated that responses to level of added enzyme differ with browse specie, so that the additive was more effective with $P$. dulce. The EFE product (Fibrozyme ${ }^{\circledR}$ ), added to some browse tree leaves can improve the fermentation kinetics in diet for goats. Further in vivo studies on the effect of EFE of the nutritive utilization of tree leaves in goats are needed.

\section{Acknowledgements}

This work was undertaken with funds from the Universidad Autónoma del Estado de México (project UAEM 2534/2007). Our gratitude also to the Mexican National Council for Science and Technology (Consejo Nacional de Ciencia y Tecnología-CONACYT) for the grant received by Daniel López Aguirre.

\section{References}

AOAC, 1990: Official Methods of Analysis, vol. II, 15th edn. Association of Official Analytical Chemists, Arlington, VA, USA

Beauchemin, K. A.; Rode, L. M.; Maekawa, M.; Morgavi, D. P.; Kampen, R., 2000: Evaluation of a nonstarch polysaccharidase feed enzyme in dairy cow diets. Journal of Dairy Science $\mathbf{8 3}$, 543-553.

Beauchemin, K. A.; Colombatto, D.; Morgavi, D. P.; Yang, W. Z., 2003: Use of exogenous fibrolytic enzymes to improve feed utilization by ruminants. Journal of Animal Science 81 (E. Suppl. 2), E37-E47.

Camacho, L. M.; Rojo, R.; Salem, A. Z. M.; Provenza, F. D.; Mendoza, G. D.; Avilés, F.; Montañez-Valdez, O. D., 2010a: Effect of season on chemical composition and in situ degradability in cows and adapted and unadapted goats of three Mexican browse species. Animal Feed Science and Technology 155, 206212.

Camacho, L. M.; Rojo, R.; Salem, A. Z. M.; Mendoza, G. D.; López, D.; Tinoco, J. L.; Albarrán, B.; Montañez-Valdez, O. D., 2010b: In vitro ruminal fermentation and energy utilization of three Mexican tree fodder species during the rainy and dry period. Animal Feed Science and Technology 160, 110-120.

Colombatto, D.; Morgavi, D. P.; Furtado, A. F.; Beauchemin, K. A., 2003: Screening of exogenous enzymes for ruminant diets: relationship between biochemical characteristics and in vitro ruminal degradation. Journal of Animal Science 81, 2628-2638.

Colombatto, D.; Mould, F. L.; Bhat, M. K.; Owen, E., 2007: Influence of exogenous fibrolytic enzyme level and incubation $\mathrm{pH}$ on the in vitro ruminal fermentation of alfalfa stems. Animal Feed Science and Technology 137, 150-162.
Cowan, M. M., 1999: Plant products as antimicrobial agents. Clinical Microbiology Reviews 12, 564-582.

El-Adawy, M. M.; Salem, A. Z. M.; Borhami, B. E.; Gado, H. M.; Khalil, M. S.; Abo-Zeid, A., 2008: In vitro caecal gas production and dry matter degradability of some browse leaves in presence of enzymes from anaerobic bacterium in NZW rabbit. In: The 9th WRSA 2008. Proceedings of the World Rabbit Congress, Verona, Italy. pp. 643-647.

France, J.; Dijkstra, J.; Dhanoa, M. S.; López, S.; Bannink, A., 2000: Estimating the extent of degradation of ruminant feeds from a description of their gas production profiles observed in vitro: derivation of models and other mathematical considerations. British Journal of Nutrition 83, 143-150.

Gado, H. M., 1997: Effect of enzymatic treatments for poor quality roughages on fiber digestibility and nitrogen meta- 
bolism in Baladi goats. Egyptian Journal of Nutrition and Feeds 1, 49-56.

Gado, H. M.; Metwally, H. M.; Soliman, H.; Basiony, A. Z. L.; El Galil, E. R., 2007: Enzymatic treatments of bagasse by different sources of cellulase enzymes. In: 11th Conference on Animal Nutrition 2007. Proceedings of Conferences of Animal Nutrition. Al-AqsorAswan, Egypt. p. 607.

García, E., 1987: Modificaciones al Sistema de Clasificación Climática de Koeppen. Universidad Nacional Autónoma de México, México $246 \mathrm{p}$.

Getachew, G.; Makkar, H. P. S.; Becker, K., 2002: Tropical browses: contents of phenolics compounds, in vitro gas production and stoichiometric relationship between short chain fatty acid an in vitro gas production. Journal of Agricultural Science 139, 341-352.

Giraldo, L. A.; Tejido, M. L.; Ranilla, M. J.; Carro, M. D., 2008: Effects of exogenous fibrolytic enzymes on in vitro ruminal fermentation of substrates with different forage: concentrate ratios. Animal Feed Science and Technology 141, 306-325.

Hove, L.; Topps, J. H.; Sibanda, S.; Ndlovu, L. R., 2001: Nutrient intake and utilization by goats fed dried leaves of shrub legumes Acacia angustissima, Calliandra calothyrsus and Leucaena leucocephala as supplements to native pasture hay. Animal Feed Science and Technology 91, 95106.

Jalilvand, G.; Odongo, N. E.; López, S.; Naserian, A.; Valizadeh, R.; Eftekhar Shahrodi, F.; Kebreab, E.; France, J., 2008: Effects of different levels of an enzyme mixture on in vitro gas production parameters of contrasting forages. Animal Feed Science and Technology 146, 289-301.

Kamalak, A.; Canbolat, O.; Gurbuz, Y.; Ozay, O.; Ozkose, E., 2005: Chemical composition and its relationship to in vitro gas production of several tannin containing tree and shrubs leaves. Asian-Australasian Journal of Animal Sciences 18, 203-208.

Kelman, W. M.; Blumenthal, M. J.; Harris, C. A., 1997: Genetic variation for seasonal herbage yield, growth habit, and condensed tannins in Lotus pedunculatus Cav. and Lotus corniculatus. Australian Journal of Agricultural Research 48, 959968.

Kung, L. J.; Treacher, R. J.; Nauman, G. A.; Smagala, A. M.; Endres, K. M.; Cohen, M. A., 2000: The effect of treat- ing forages with fibrolytic enzymes on its nutritive value and lactation performance of dairy cows. Journal of Dairy Science 83, 115-122.

Makkar, H. P. S.; Singh, B., 1991: Distribution of condensed tannins (proanthocyanidins) in various fractions of young and mature leaves of some oak species. Animal Feed Science and Technology 32, 253-260.

Makkar, H. P. S.; Aderibigbe, A. O.; Becker, K., 1998: Comparative evaluation of a non-toxic and toxic variety of Jatropha curcas for chemical composition, digestibility, protein degradability and toxic factors. Food Chemistry 62 , 207-215.

Mangan, J. L., 1988: Nutritional effects of tannins in animal feed. Nutrition Research Reviews 1, 209-231.

Mauricio, R. M.; Mould, F. L.; Dhanoa, M. S.; Owen, E.; Channa, K. S.; Theodorou, M. K., 1999: Semi automated in vitro gas production technique for ruminant feedstuff evaluation. Animal Feed Science and Technology 79, 321-330.

McAllister, T. A.; Bae, H. D.; Jones, G. A.; Cheng, K. J., 1994: Microbial attachment and feed digestion in the rumen. Journal of Animal Science 72, 3004-3018.

McAllister, T. A.; Hristov, A. N.; Beauchemin, K. A.; Rode, L. M.; Cheng, K. J., 2001: Enzymes in ruminant diets. In: M. R. Bedford, G. G. Partridge (eds), Enzymes in Farm Animal Nutrition. CABI Publishing, Wallingford, Oxon, U.K, pp. 273-298.

McSweeney, C. S.; Palmer, B.; McNeill, D. M.; Krause, D. O., 2001: Microbial interactions with tanning polyphenolics: nutritional consequences for ruminants. Animal Feed Science and Technology $\mathbf{9 1}$, 83-93.

Menke, K. H.; Steingass, H., 1988: Estimation of the energetic feed value obtained from chemical analysis and in vitro gas production using rumen fluid. Animal Research and Development 28, 7-55.

Miller, D. R.; Elliott, R.; Norton, B. W., 2008: Effects of an exogenous enzyme, Roxazyme ${ }^{\circledR}$ G2 Liquid, on digestion and utilization of barley and sorghum grain-based diets by ewe lambs. Animal Feed Science and Technology 140, 90-109.

Moharrery, A.; Hvelplund, T.; Weisbjerg, M. R., 2009: Effect of forage type, harvesting time and exogenous enzyme application on degradation characteristics measured using in vitro technique.
Animal Feed Science and Technology 153, 178-192.

Morgavi, D. P.; Beauchemin, K. A.; Nsereko, V. L.; Rode, L. M.; McAllister, T. A.; Wang, Y., 2004: Trichoderma enzymes promote Fibrobacter succinogenes S85 adhesion to, and degradation of, complex substrates but not pure cellulose. Journal of the Science of Food and Agriculture 84, 1083-1090.

Nsereko, V. L.; Morgavi, D. P.; Rode, L. M.; Beauchemin, K. A.; McAllister, T. A., 2000: Effects of fungal enzyme preparations on hydrolysis and subsequent degradation of alfalfa hay fiber by mixed rumen microorganisms in vitro. Animal Feed Science and Technology 88, 153-170.

Okuda, T.; Yoshida, T.; Hatano, T., 1993: Classification of oligomeric hydrolysable tannins and specificity of their occurrence in plants. Phytochemistry 32, 507521.

Peng, H.; Revell, D.; McSweeney, C. S.; Brooker, J. D., 2005: Effect of different non-protein amino acids on in vitro dry matter digestibility of Lucerne chaff. Animal Feed Science and Technology 121, 139146.

Rakhmani, S.; Brooker, J. D.; Jones, G. P.; Palmer, B., 2005: Composition of condensed tannins from Calliandra calothyrsus and correlation with in sacco digestibility. Animal Feed Science and Technology 121, 109-124.

Ramírez, L.; Aranda, E.; Mendoza, G.; Landois, L.; Miranda, L.; Crosby, M., 2005: Characterization of commercial fibrolytic products for ruminant diet. Veterinaria México 35, 1-9.

Reed, J. D., 1986: Relationship among soluble phenolics, insoluble proanthocyanidins and fiber in east African browse species. Journal of Range Management 39, 5-7.

Rubanza, C. D. K.; Shem, M. N.; Otsyina, R.; Ichinohe, T.; Fujihara, T., 2003: Nutritive evaluation of some browse tree legume foliages native to semi-arid area in western Tanzania. Asian-Australasian Journal of Animal Sciences 16, 1429-1437.

Salem, A. Z. M.; Salem, M. Z. M.; ElAdawy, M. M.; Robinson, P. H., 2006: Nutritive evaluations of some browse tree foliages during the dry season: secondary compounds, feed intake and in vivo digestibility in sheep and goats. Animal Feed Science and Technology 127, 251-267. 
SAS Institute, 2002: SAS User's Guide: Statistics. Ver 9.0. SAS Institute, Cary, NC, USA

Szumacher-Strabel, M.; Cieślak, A., 2010: Potential of phytofactors to mitigate rumen ammonia and methane production. Journal of Animal Feed Sciences 19, 319-337.

Theodorou, M. K.; Williams, B. A.; Dhanoa, M. S.; McAllan, A. B.; France, J.,
1994: A simple gas production method using a pressure transducer to determine the fermentation kinetics of ruminant feeds. Animal Feed Science and Technology 48, 185-197.

Van Soest, P. J.; Robertson, J. B.; Lewis, B. A., 1991: Methods for dietary fibre, neutral detergent fibre, and non-starch carbohydrates in relation to animal nutrition. Journal of Dairy Science 74, 3583-3597.
Wina, E.; Tangendjaja, B.; Susana, I. W. R., 2005: Effects of chopping, and soaking in water, hydrochloric acidic and calcium hydroxide solutions on the nutritional value of Acacia villosa for goats. Animal Feed Science and Technology 122, 79-92. 